Pirineos, 158-159: 127 a 147, J $\mathrm{JCA}_{i} 2004$

\title{
RODENT COMMUNITIES IN THE SUB-POLAR URAL MOUNTAINS
}

\author{
K. I. BERDYUGEN \& V. N. BOLSHAKOV \\ Itstitute of Plant And Animal Ecology UD RAS \\ 620144 Ekaterinburg, Russia.
}

\begin{abstract}
Distribution of the rodent communities in the Sub-polar Utrals is analysed. This part of the range, betueen $64^{\circ}$ and $66^{\circ} \mathrm{N}$, includes the highest perks, is very scarcely settled and has been rarety studied. However, the area is interesting for biogeograpiny, being a border zone separating Europent and Siberian lowland faunas. Comparison of results with those from expeditions tindertaken in 1927 and in 1972, allows to evaluate changing frends in the local rodent communities, and to relate these trends to changes in the enoironnental conditions. The results fielp to emphasize the barrier role played by Sub-polar Lrals for the species of rodents inhtabiting both sides of the range, and also show the shifting of southern rodent forms northwards, or the moving upuards of other lowland species. This could be seen as an additional evidence of current climate warming trends.
\end{abstract}

RÉSLMÉ.-On artalyse la répartition des communautés de rongeurs dans les Ourals Subpolaires, une section de la chaine comprise entre les $64^{\circ}$ et les $66^{\circ}$ de latitude $N$. Cette partie est très peu peuplée, elle possede les pics tes pius hauts de la chafine et a été rarement etudiée. Il s"agit d'une région intéressonte, car c'est la frontière entre les plaines européennes et les plaines orientales de la Silherie. En comparant les observations effectueses en 1927 et en 1972 avec celles des demieres annes, on peut voir les tendances de changentent des groupements de rongeurs de ia région, et les interpréter en fonction des changements dans i"environnement. Les résultats permettent de mieux comprendre le rôle de barrière qui jouent les Ourals Subpolaires pour les especes de rongeurs situées a"th coté et d'autre de la chaine. Aussi, ils permettent de verifier le déplacement vers le nord de formes méridionales et l'élébation en altitude d'autres, ce qui pourrait être ou comme une presve additionnelle de la tendance au réchouffement global.

RESUMEN-Se analiza la distribución de las comunidades de roedores en los Unales Sulpolares, comprendidos entre los 64 y $66^{\circ}$ de latitud $N$. Esta zona posee pocos asentamientos humanos, incluye las cumbres this ailas de la cordiliera, y ha sido poco 


\begin{abstract}
estudinda. Su interés consiste en que se trnta de una zoma fronteriza, que separn las comunidades de las llamurns enropens y siberinms. La comparación con los resultados de obserunciones efectundas en 1927 y em 1972 permite eunlun las tendencias de cambio en lins comunidades de roedores de la zona, e interprelarlas en función de cambios en las condiciones ambientales. Los resultados permiten comprender el papel de barrera representado por los Linales Subpolores para las especies de roedores situmdas a uno u ofro lado de la cordillern. También permiten constatar el aonnce hacin el norte de formos meridionales o el ascenso en altitud de otras, to que podrá constituir uon pruteba adicional de la actual tendencin al calentamiento globnl.
\end{abstract}

\title{
1. Introduction
}

The Sub-polar Urals is a territory of considerable interest for zoologists and other specialists in the field of mountain environments because it is the highest part of Urals Mountains with pronounced altitudinal zonality and is also nearly a wilderness area. Besides, this region is the least studied one in the Urals in every respect, including its scantly known biota zoocomponent. Of special interest is the fact that the range borders of a series of species pass on the territory of the Sub-polar Urals. The perspective of intensification of economic development of Sub-polar Urals requires a prior comprehensive study of fauna as a necessary basis for its preservation and proper management in the future as a part of the region's sustainable development.

Up to the present, fauna of the Sub-polar Urals was known mainly by results of several research expeditions occurred in the XVIII, XIX and first half of the XX centuries (ARHIPOVA \& YASTREBOV, 1971; MARVIN, 1957). Zoological explorations in these expeditions were aimed primarily at trade species. Though mammalia species lists of the studied region were compiled, the description of small rodents (Myomorpha) were not completed. The most detailed description of this group of mammals was done by K. K. FLEROV (1933) who had been to the Sub-polar Urals as a member of North Urals complex expedition of AN SSSR in 1927. In 1968-1972 a group of zoologists from Komi research center of RAS UD headed by V. V. TUR'EVA $(1970,1971,1977)$ carried out inspection of mammalian fauna (including Myomorpha) of the western slope of the Sub-polar Urals (on the latitude of Sablya mountain range).

\section{Materials and Methods}

The bulk of materials for the given work were gathered over a period of years during expeditions and stationary research in all principal landscape areas of the eastern slope of the Sub-polar Urals. 
Rodent communities structure is characterized by species composition and relative abundance of species. The latter was calculated using relative numbers values that in span-trap capture conventionally measured by the number of animal specimens captured in 100 trap-days. To estimate rodents populations structure, diversity parameters were also used: Shannon-Weaver diversity index (?') estimating strictly the diversity and inequitability index (U) reflecting total heterogeneity (irregularity) of species, abundance distribution and, along with the dominant species share, the degree of monodominance in the community (MAGURRAN, 1992; PESENKO, 1982). All these three indices despite their interrelations are in our opinion necessary for description of the study of animal groups as no particular index meets the requirements of a full description of integral characterization. Analytic expression of Shannon-Weaver index applied in the given study is of the form (MAGURRAN, 1992; PESENKO, 1982):

$$
\mathbf{H}^{\prime}=-\sum_{\mathbf{i}=1}^{S} \mathrm{P}_{\mathbf{i}} \operatorname{l-n} \mathbf{P}_{\mathrm{i}}
$$

where $P_{i}$ is a share of species $i(i=1 \ldots s)$ and $S$ - total number of species. Inequitability index is expressed by the formula (PESENKO, 1982):

$$
\mathrm{U}=\sum_{\mathrm{i}=1}^{\mathrm{S}} \mathrm{P}_{\mathrm{i}}^{2}-1 / \mathrm{S}
$$

where $P_{i}$ and $S$ are the same as in (1).

Degree of individual communities similarity in species composition was estimated by Ochiai index (OCHIAI, 1957) with the formula:

$$
\mathrm{I}_{0}=\frac{\mathrm{C}}{\sqrt{\mathrm{AB}}}
$$

where A, B - numbers of species in two compared lists, $C$ - number of common for both lists species. Resemblance by quantitative characteristics (by species ratio) was measured by extended Ochiai-Barkman index (PESENKO, 1982) with the formula:

$$
I_{\mathrm{OB}}=\frac{\sum \mathrm{P}_{\mathrm{ij}} \mathrm{P}_{\mathrm{ik}}}{\sqrt{\sum \mathrm{P}_{\mathrm{ij}}{ }^{2} \sum \mathrm{P}_{\mathrm{ik}}{ }^{2}}}
$$

where $P_{i j}$ is a share of species $i$ in collection $j, P_{i k}$ is a share of species $i$ in collection $\mathrm{k}$. 
When examination of general structure of similarities over the entire set of compared communities was necessary, tree plots were built basing on similarity indices matrixes according to the scheme suggested by V. L. ANDREEV (1979) and modified in accordance with the indices used. For matrix reduction similarity indices values for combined rows and coltmms were calculated as geometrical means of two combined indices by the formula:

$$
I_{d k_{r}}=\sqrt{I_{k} I_{i}}
$$

where $k, j=[1 \ldots n]-$ amounts of rows and columns in the original matrix; $k^{\prime}$, $j^{\prime}=[1 \ldots(n-1)]-$ same values in the reduced matrix on each reduction step. In a number of cases in addition to the above mentioned similarity indices a combined measure was used as expressed with the formula:

$$
I_{u I}=\sqrt{I_{0} I_{0 b}}
$$

where $I_{0}$ and $I_{0 b}$ are the above described indices. The suggested index proved to be of good resolving power, because it removed a series of leveling factors, inherent in each of individual indices involved in formula.

\section{Results and Discussion}

The Sub-polar Urals includes territory within the Ural mountains and extend to $240 \mathrm{~km}\left(64^{\circ} 00-65^{\circ} 40^{\prime \prime} \mathrm{N}\right)$ from the upper reaches of the river Hulga to the latitudinal part of Schugor river. The highest mountains of the Ural range (Naroda, Karpinskogo, Manaraga, Sablya and other ) are located within the Sub-polar Urals. In its central part the mountain range broadens up to $150 \mathrm{~km}$. Three main orographic elements constitute the Sub-polar Urals: the Issledovatelskiy range and the Narodo-Ityinskiy ridge form the Bolshoi (Kamenniy) Ural with its pronounced alpine relief and the Maliy (Lesnoy) Ural range with a smoother relief, this is adjacent to Bolshoy from the east.

A. N. MAKUNINA (1976) describes the Sub-polar Urals as a landscape region with two provinces: Western and Hulginsko-Manyinskaya, these occupy the western and eastern slopes of this part of the Urals. These two provinces are dramatically different in climate, chiefly due to greater amount of precipitation on the western slopes in comparison with the eastern (KEMMERIH, 1961). Sub-polar Urals landscapes are characterized by pronounced vertical zonality. Mountain taiga forests reach $600 \mathrm{~m}$; open woodlands of goltsy belt, mountain tundras and goltsy deserts occupy still higher altitudes. However, due to mesorelief specific features a rigid vertical zonality is dis- 
RODENT COMMLNITTES IN THE SUB-POLAR URAL MOUNTAIRS

Table 1. Species composition of rodent (Myomorpha) fauna in the Sub-polar Urab.

\begin{tabular}{|c|c|c|c|}
\hline \multirow[b]{2}{*}{ Taxon } & \multirow{2}{*}{\begin{tabular}{|c|} 
Western slope \\
According to \\
V. V. TUR'EVA (1977)
\end{tabular}} & \multicolumn{2}{|c|}{ Eastern slope } \\
\hline & & $\begin{array}{l}\text { Accordingto } \\
\text { K.K. FLEROV (1933) }\end{array}$ & our data \\
\hline Clethrionomys rutilus & & & \\
\hline $\begin{array}{l}\text { Northern red-backed vole } \\
\text { Clethrionomys rufocartus }\end{array}$ & + & + & + \\
\hline $\begin{array}{l}\text { Grey large-footed red-backed vole } \\
\text { Clethrionomys glareolus }\end{array}$ & + & + & + \\
\hline $\begin{array}{l}\text { Common red-backed vole } \\
\text { Microtus oeconomus }\end{array}$ & + & - & + \\
\hline $\begin{array}{l}\text { Root vole } \\
\text { Microtus agrestis }\end{array}$ & + & + & + \\
\hline $\begin{array}{l}\text { Short-tailed field vole } \\
\text { Microtus middendorffi }\end{array}$ & + & + & + \\
\hline $\begin{array}{l}\text { Middendorf's vole } \\
\text { Arvicola terresiris }\end{array}$ & - & + & + \\
\hline $\begin{array}{l}\text { European water vole } \\
\text { Myopus schisticolor }\end{array}$ & + & + & + \\
\hline $\begin{array}{l}\text { Wood lemming } \\
\text { Dicrostory } x \text { torquatus }\end{array}$ & + & - & + \\
\hline $\begin{array}{l}\text { Collared lemtring } \\
\text { Sicista betalint }\end{array}$ & - & + & + \\
\hline Northern birch mouse & + & - & + \\
\hline
\end{tabular}

rupted. This 'mix-up' of vertical belts leads to the creation of an intricate mosaic of bigeocenose types at different altitudinal levels.

Rodent fauna of the Sub-polar Urals is represented by ten zonal or azonal species, living in natural habitats (Table 1) and two synanthropic species (Rattus noroegicus and Mtus musculus) occurring only in human settlements. All species living in natural habitats are widespread forms whose ranges go far beyond the limits of Urals region. All species (with one exception) also inhabit plains adjacent to the motuntainous Urals, at least within their preferred landscape zone. One species - Clethrionomys rufocanus in the Urals mountains is represented by relatively isolated group of populations. However this isolation of the Urals populations of grey large-footed red-backed vole didn't give rise to any substantial morphological distinctions (BOLSHAKOV, 1972; BOLSHAKOV et al., 1986; BOLSHAKOV \& BERDYUGIN, 1990). This demonstrates either a recent isolation or the existence of temporary contacts with populations of this species in other parts of the area through area bridges or corridors (BERDYUGIN, 1984). This character of Sub-polar Urals rodent fauna demonstrates the comparatively recent time of its formation, which is also supported by geographical data (MAKUNINA, 1976). 
Another characteristic feature of the rodent species composition of this section of the Ural Mountains is overlapping of ranges of some species whose habitat bulks lie in opposite directions and the territory under investigation is also border. The Sub-polar Urals is inhabited by more "southern" species common red-backed vole, northern birch mouse (north-eastern range limit) and "northern" species - Middendorf's vole (south-westem border), collared lemming (southern border). Presumably the northern limit of wood lemming distribution in the Ural mountains passes here. At least none of the authors recorded this species for the Sub-polar Urals (BALAHONOV, 1981; BOYKOV, 1981; TOPORKOVA, 1957; FLEROV, 1933). Apparently such species composition of rodents is determined by specific geographical conditions described above.

A comparison of rodent species lists compiled by V. V. TUR'EVA (1977), $\mathrm{K}$. K. FLEROV (1933) and reveals some current distinctions between faunas of different slopes and temporal changes of species composition on the eastern slope (the area examined by K.K. Flerov is within the territory we studied but his work had been accomplished about 50 years earlier than ours). As evident from the data given in table 1 Flerov's list lacks three species in comparison with ours. Two of them (northern birch mouse and common red-backed vole) are distributed mainly to the south from the investigated area. On the contrary Tur'eva's list in comparison with ours, lacks two species (Middendorf's vole and collared lemming) whose ranges lie mainly to the north from considered territories. Tur'eva's and Flerov's lists when compared differ even more: in this case only five shared species are present. The first list lacks "northern" species (Middendorf's vole and collared lemming), the second "southern" ones (common red-backed vole, wood lemming, northern birch mouse). Thus, the three compared species lists reflect features of rodent local faunas of different slopes of the Sub-polar Urals. These are related to their specific environmental conditions and changes that eastern slope fauna underwent over approximately semi-centennial period and that are probably associated with temporal dynamics of natural conditions.

For quantitative assessment and more detailed analysis of similarity (difference) between the three species lists we use the Ochiai similarity index values (OCHIAI, 1957). Value of for ours and Tur'eva's lists constituted $89 \%$, for ours and Flerov's lists $-84 \%$, and for Tur'eva's and Flerov's lists $-67 \%$. As presented values of indicate, the similarity degrees between our and both cited authors data are nearly the same. Similarity between Tur'eva's and Flerov's lists is much less. So, thus rodent fauna of the eastern slope changed in the past 50-60 years as much as faunas of the two slopes presently differ. These changes associated with appearance of southern forms that were absent in Flerov's list, in ours (Table 1). More "northern" nature of fauna of 
the eastern slope in comparison with the western corresponds to more cold and continental climate to the east from watershed, in particular, more severe winter conditions with a lower precipitation (KEMMERIH, 1961), that affect rodents wintering conditions. Thus, modern rodent fauna of the eastern slope of the Sub-polar Urals has an intermediate nature between relatively "southern" ("european") modern fauna of the western slope and the relatively "northern" ("siberian") fauna described on the eastern slope five decades ago. Differences in species composition between western and eastern slopes are not only determined by present weather and climatic conditions but also related to the history of formation of modern ecosystems in the Sub-polar Urals. Quaternary sediments research data (LIDER, 1976) indicate that northen parts of the Urals (beginning from $62^{\circ} \mathrm{N}$ ) were cleared from the glacier cover most probably in the end of Upper Pleistocene. It is not improbable that the central part of the Sub-polar Urals was also glaciated in the Holocene. In any case during the degradation of the ice sheet and the formation of Subpolar Urals biota the watershed part of Urals mountain range served as physiographic barrier to dispersal of "eastern" species to the west and "western" to the east for a long time. When current state of rodents' ranges is considered (BERDYUGIN, 1984; GROMOV \& POLYAKOV, 1977), this barrier is more significant for "western" ("southern") species than for "eastern" ("northern"). The northern red-backed vole in particular is widespread in the north of Europe while common red-backed vole spread the east (to the Southern Siberia where it has fairly wide distribution) evidently much further the described area- through the Middle Urals and forest-steppe belt (or subtaiga forests belt) of Western Siberia.

Table 2. Assessment of some rodent species abundance in the Sub-polat Urals.

\begin{tabular}{lcccc|}
\hline Species & V.V. Tur'eva's (1977) list & our list & K.K. Flerov's (1933) list \\
\hline Common red-backed vole & +++ & +++ & \\
Wood lemming & ++ & + & - \\
Collared lemming & + & + & +++ \\
\hline Note: $(-)$ the species is absent; $(+)$ only individual specimens were captured; $(++)$ rare speries, and $(+++)$ \\
common species.
\end{tabular}

The character of the limits of some of the rodent species ranges in the Subpolar Urals give evidence to different sources of slopes faunas formation: European (south-western) and Siberian (north-eastern). At the same time the reality of some species invasion from the south along Urals mountain range as glaciers retreated to the north should be supposed. In particular, grey large-footed red-backed vole in our opinion originally appeared in the Urals 
in southward areas that were free from glacier, from whence it spread to the north of Western Europe - to Scandinavia via a "corridor" in the eastern Europe southern taiga belt and in the Urals dispersed along the mountain range to the north up to the Polar Urals, as ice cover retreated from its northem parts. The question about tundra rodent species invasion toutes to this area still remains unsolved. The major part of their range presently lies to the north and to the east of the Sub-polar Urals. Penetration of these species from the north appears to be improbable because the formation of fauna of the western Siberian tundra would not have occurred before the formation of rodent population in mountain tundra of the Sub-polar Urals.

The differences between the three species lists look more significant when quantitative assessments of some species abundances are compared (Table 2). It is evident that the frequency of common red-backed voles and wood lemmings is less to the east of watershed than to the west, and 50 years ago these species were not recorded here. Collared lemming, conversely, is absent to the west of watershed, and only individual specimens of it presently occur on the eastern slope while 50 years ago it was a common species here. The spatial and temporal changes of rodents abundance indicates the existence of a trend to alteration of the eastern slope species composition towards its enrichment with "southern" forms and reduction of "northern" forms number. We do not judge that this tendency is of historical character though evidences of progressive melting of modern glaciers in the Polar and Sub-polar Urals (KEMMERIH, 1961) show changes of species composition with general warming of climate. Although exchange between faunas of the western and eastern slopes has increased recently owing to increase of accessibility to watersheds. Species composition is also labile and the process of formation of fauna in the studied area is continuing. This is further evidence of historical youth of the described faunistic complex. It should be noted that the tendencies of temporal changes of species composition in the Sub-polar Urals coincide with their character with those described in the Middle and North Urals (BERDYUGIN, 1999).

The revealed distinctions between recent faunas of western and eastern slopes were investigated more comprehensively, extending the studied territory to the foothill plains. Comparison of species lists of local rodent faunas of four landscape plots of the Sub-polar Urals that included foothill plain and mountainous part of the western slope and foothill plain and mountainous part of the eastern slope were conducted. Rodent species composition of foothill flood plain of the western slope (TUR'EVA, 1977; TUR'EVA et al, 1979) was identical to that cited above for mountainous part (BOLSHAKOV \& BERDYUGIN, 1986; TUR'EVA, 1977). The situation is different on the Siberian side, here we recorded only five rodent species - northern red- 
backed, common red-backed, root, Middendorf's and European water voles. Ochiai similarity indices $\left(\mathrm{I}_{0}\right)$ for different species lists pairs (Table 3 ) above the diagonal clearly demonstrate the degree of distinction existing between compared landscape plots of the Sub-polar Urals. Similarity of foothill floodplain fauna with those of other sites monotonically decreases in consistence with movement to the east through the mountain range. The species lists of the mountainous part of the western slope and eastern sites is the same. Besides this similarity between adjacent plots, species lists also decreases in the eastward direction so that the minimum similarity among all neighboring sites is recorded for the mountainous part and foothill plain part of the eastern slop (Table 3, values adjacent to matrix diagonals). Quantitative similarity indices between eastern foothill plain and other sites of the Sub-polar Urals faunas are as large as, for example, between faunas of upper mountain belts of different geographical regions of the Urals range, in particular, between faunas of the Sub-polar Urals, Polar Urals and different areas of the North Urals (BOLSHAKOV \& BERDYUGIN, 1986; 1990). The large differences in the similarity indices within comparatively small distance change is due to increase of rodent species number in the mountainous part of the eastern slope and its sharp decrease on the foothill plain.

Table 3. Ochiai similarity indices for species lists (above diagonal) and extended OchiaiBarkman similarity index (below diagonal) for different landscape plots of Sub-polar Urals.

\begin{tabular}{|lcccc|}
\hline & 1. & 2. & 3. & 4. \\
\hline 1. Western slope. Foothill plain & - & 1.00 & 0.89 & 0.63 \\
2. Western slope. Mountainous part & 0.81 & - & 0.89 & 0.63 \\
3. Eastem slope. Mountainous part & 0.82 & 0.84 & - & 0.71 \\
4. Eastem slope. Foothill plain & 0.72 & 0.96 & 0.80 & - \\
\hline
\end{tabular}

Deficiency of rodent species composition in this area is in no way determined by general species deficiency of rodent faunas of north and middle taiga subzones of West Siberia. 11 species were recorded for this region by different authors (BALAHONOV, 1981; POKROVSKAYA, 1983; RAEVSKIY, 1982; RAMASANOVA, 1984) and 8-9 species are commonly present in any concrete area fauna. We do not undertake to specify causes of species composition reduction in the studied area, but we suppose them to be of ecological nature, ensuing from local environmental conditions.

An evidence of that is the high degree of similarity in such remote areas as Verhnuaya Sinya basin (TUR'EVA, 1979) and Malaya Sosva upper reaches (RAEVSKIY, 1982; RAMASANOVA, 1984), which has the value of $=0.88-0.89$ 
on the one hand and also the poor species composition in some other areas of West Siberia, for example in Ob river Shurishkarskaya flood lands (BALAHONOV, 1981) or in Nadim middle stream basin (POKROVSKAYA, 1983).

Table 4. Relative numbers (numerator) and share (denominator) of five rodent species in

\begin{tabular}{|c|c|c|c|c|}
\hline \multirow[t]{2}{*}{ Vole species } & \multicolumn{2}{|c|}{$\begin{array}{l}\text { Westerr slope } \\
\text { (By V.V TUR'EVA, 1977)* }\end{array}$} & \multicolumn{2}{|c|}{$\begin{array}{l}\text { Eastem slope } \\
\text { (Our data) }\end{array}$} \\
\hline & $\begin{array}{l}\text { Foothill } \\
\text { plain (1) }\end{array}$ & $\begin{array}{c}\text { Mountainous } \\
\text { part (2) }\end{array}$ & $\begin{array}{c}\text { Mountainous } \\
\text { part (3) }\end{array}$ & $\begin{array}{l}\text { Foothill } \\
\text { plain (4) }\end{array}$ \\
\hline Northern red-backed & $5,2 / 41,3$ & $2,6 / 63,4$ & $3,9 / 46,2$ & $3,6 / 96,2$ \\
\hline Grey large-footed red-backed & $0,3 / 2,4$ & $0,1 / 2,4$ & $2,4 / 28,4$ & 0,0 \\
\hline Common red-backed & $4,9 / 38,9$ & $0,3 / 7,3$ & $1,6 / 18,9$ & $0,04 / 1,1$ \\
\hline Short-tailed field & $0,9 / 7,1$ & $0,6 / 14,6$ & $0,5 / 5,9$ & 0,0 \\
\hline Root & $1,3 / 10,3$ & $0,5 / 12,2$ & $0,05 / 0,6$ & $0,1 / 2,7$ \\
\hline Sum (Total) & $12,6 / 100,0$ & $4,1 / 99,9$ & $8,45 / 100,0$ & $3,74 / 100,0$ \\
\hline $\mathbf{H}^{\prime}$ & 1,244 & 1,107 & 1,227 & 0,184 \\
\hline Inequitability index & 0,138 & 0,244 & 0,133 & 0,593 \\
\hline
\end{tabular}

Table 5. Integrated similarity indices for different Sub-polar Urals landscape plots faunas

\begin{tabular}{|ccccc|}
\hline & 1 & 2 & 3 & 4 \\
\hline 1 & - & 0,90 & 0,85 & 0,67 \\
3 & - & - & 0,86 & 0,78 \\
4 & - & - & - & 0,75 \\
Note. Landscape plots numbers as in table 3. \\
\hline
\end{tabular}

We conclude that fauna formation in mountainous part of the eastern slope could not be solely on the basis of adjoining plain fauna. By the same token neither is it isn't the result of intermingling of western and eastern faunas due to the difference in elements lacking in them.

Species composition changes do not reflect all the nuances of rodent community changes on different landscape plots of the Sub-polar Urals because species ratio also plays an essential part. Table 4 contains data on relative numbers (on span-traps capture data) and tatios of five most abundant on the given territory species. The extended Ochiai-Barkman similarity index was calculated for these incomplete lists. The obtained values are presented in table 3 in the above-diagonal squares. Data from Tables 3 and 4 show that rodent assemblages of the Sub-polar Urals significantly differ by the roles of 
particular species in assemblages of different plots. Two species - northern red-backed and common red-backed voles dominate on the western foothill floodplain. Similarly both species predominate in the most part of flat territory of Komi Republic (TUR'EVA, 1952; KUPRIYANOVA \& NEDOSEKIN, 1986). They are followed by root vole, a little less abundant is short-tailed field vole and the least numerous is grey large-footed red-backed vole. In the western mountainous part northern red-backed vole clearly predominates over all species and two Microtus species are subdominant. Common redbacked vole abundance here is lower than abundance of each Microtus species in contrast to foothill floodplain. Grey large-footed red-backed vole are not numerous. The Ochiai-Barkman similarity index for these plots differs quite significantly from 1 . The Northern red-back vole dominates in eastern mountainous part as well as in western region. The grey large-footed red-backed vole comes to the second place.

The third most frequent is common red-backed vole, which in the eastern slope mountains appeared to be more abundant than on the western slopes. It's interesting because the latitude of Sub-polar Urals is the eastern border of this species distribution and consequently one could most probably expect gradual dropping of grey large-footed red-backed vole abundance to the east (from the first landscape plot to the fourth). Causes of this anomalous increase in frequency on the eastern slope in comparison with western remains unresolved.

The short-tailed field vole is next in the order of decrease. Its abundance here is approximately the same as in the western mountainous part. Root vole numbers are low in the eastern mountainous part. It was registered mainly on the secondary ruderal boggy plots and pyrogenous bogs. Causes of this species low abundance are also not completely clear. Probably it is connected with a low level of suitable root vole habitats, namely grasssedgy bogs with tussocks, to the east of the Urals. Ochiai-Barkman indices of similarity between faunas of this plot and western ones are close to each other and also to the index of similarity between western plots. The same levels of distinctions between faunas from three described areas show that this similarity index is unable to reflect some substantial aspects of differing species ratios in compared faunas. On the eastern foothill plain, northern red-backed vole dominates. The abundance of root vole, which appears to inhabit in this area usually, in grass-sedgy bogs with tussocks, is several times lower. Abundance of common red-backed vole is still lower. It should be noted that this frequency could increase substantially in the foothill plain over time. In addition to the enumerated species the only specimen of Middendorf's vole that was seen was captured on this plot, in a habitat not typical for this species. It is impossible to state with certainty the likelihood 
of its presence in this area. Causes of absence of short-tailed field vole on the foothill plain are unclear. Even if this species remained unrevealed by our captures, its abundance is undoubtedly lower than of common red-backed vole. At the same time it occurs in notable numbers on the mountainous part of the eastern slope, as well as to the north-east (POKROVSKAYA, 1983) and south-east (RAEVSKIY, 1982; RAMASANOVA, 1984) of the considered region. Eastern foothill plain fauna is most similar to that of western mountainous plot and least to western foothill floodplain in compliance with Ochiai-Barkman similarity indices (Table 3). The index of similarity with adjoining eastern mountainous plot has an intermediate value. Correlation of fauna indices of similarity between eastern foothill and western plots with frequency distributions in each of these plots shows that the index value is determined by a degree of dominance by the one most abundant species in this case. Low-numbers species "tail" virtually doesn't affect its value. Close values of indices of similarity between both mountainous plots, western foothill flood plain and each of mountainous plots, eastern foothill and eastern mountainous plots are determined by the same factor. Thus, each of the employed similarity indices has its defects but also possesses advantages not found in the others. Ochiai index accounts presence of one or other species in fauna lists and Ochiai-Barkman index assesses to a certain (though not sufficient) degree distribution of species abundances, or in more exact terms, level of the dominant species predominance (probably other analogous similarity indices have similar advantages). In our opinion it would be useful to build some similarity index uniting both these parameters in which their defects would be mutually cancelled out, though not reducing the relevant advantages. A version of such an index () suggested by us is described in the Materials and methods section. Obtained values of combined similarity index are presented in Table 5. Data of the table show that similarity between western foothill plain and the other plots is monotonically decreasing for the territories situated further to the east. Similarity indices for the eastern foothill plain and the other plots are the least among all other compared pairs. Similarity between faunas of adjoining plots is also monotonously decreases as compared pairs shift in the eastward direction (values in the cells immediately adjacent to the diagonal). That is to be expected: the first compared pair differs only in the species distribution, in the third pair the same differences are more pronounced and they also differ in species composition. When comparing eastern foothill plain with other areas the similarity index remained the greatest for the western mountainous plot (due to resemblance in degree of predominance of the dominant species), but this was lower than indices in the other compared pairs $(1-2 ; 1-3 ; 2-3$; Table 5), thus reflecting a greater difference in the 
number of species in the compared lists. These differences in the numbers of species in the lists, remained hidden when comparing extended OchiaiBarkman similarity indices (Table 3, values under diagonal). Similarity indices for the eastern mountainous plot and the western foothill and mountainous plots are close, which is also to be expected as differences in species numbers are equal (Table 4; Figure 1): predominance in one case is more and in the other less pronounced than on the eastern mountainous plot. Thus, the suggested index adequately describes differences (similarities) between faunas from individual plots. Certainly the new similarity index requires comprehensive examination and we suggest to those who are interested to further examine it using their materials. On this point this small methodical deviation is over and we return to analysis of the essence of distinctions between faunas of individual landscape plots of Sub-polar Urals.

Diversity parameters characterizing rodent communities of different areas of the Sub-polar Urals are presented in Table 4. Five species were included in calculations to estimate a similarity index. These data indicate that the maximum diversity index value was a characteristic for the western foothill floodplain. In communities of the mountainous part of the eastern slope this index is a little lower and still less in the western mountainous part and minimum on the eastern foothill plain. The value of the considered parameter is greater in mountainous part of the Sub-polar Urals than in the North and Middle Urals. The mere fact that diversity of rodent population is greater in the northern area than in southern is very interesting and indicates some peculiar features inherent to this part of the Urals. With identical species composition



Figure 1. Diagram of species abundances distributions in different landscape areas of Sub-polar Urals (1-4, numbers of landscape plots as in Table 3). 
of rodent communities, relatively high diversity in the eastern mountainous part owe their origin to more equalized species ratios resembling those characteristics of the western foothill flood plain (though resemblance is attained at the cost of different community components).

It is therefore appropriate to consider more closely inequitability index.

Table 4 illustrates that fauna of the eastern foothill plain is the most monodominant and faunas of eastern mountainous part and the western foothill flood plain are the most polidominant. Monodominance of the western mountainous part is significant and thus a high similarity index value was obtained from quantitative data when comparing this area with eastern foothill plain. The difference in directions of fauna changes between eastern mountainous and western plots can be explained: in fauna of this plot in comparison with western foothill flood plain, substitution of the co-dominant species takes place (grey large-footed red-backed vole instead of common red-backed) while maintaining the same degree of monodominance, while in the western mountainous part, co-dominants shift their status to subdominance.

A high degree of monodominance in rodent communities on the eastern foothill plain is consistent with rodent communities, monodominance characteristics for the whole taiga belt of the Western Siberian lowland. Northern red-backed vole predominates, including the described area. In our opinion this is a result of high degree of habitat homogeneity in the given region. On the other hand, a significantly less degree of monodominance of population of the mountainous part of the eastern slope as well as more rich species composition is due to highly heterogeneous environment resulting from highly dismembered landscape of this plot.

Causes of greater inequitability of communities of western mountainous part in comparison with western foothill plain are not quite clear. Biotopes of the plains are usually rather monotonous though species composition there may be much more diverse. The greater diversity of habitats in the mountains should have compensated for this effect and values of the described parameter should at least be close to each other. Most probably habitats on the foothill floodplain have more favorable conditions for different rodents species in spite of their high uniformity than habitats in mountainous part of the western slopes which provide heterogeneous but more severe conditions. However in mountainous part of the eastern slope where inequitability is lower, living conditions are in no way less severe than on the western slope. Corroboration of this factor concerning rodent communities productivity can be found on different landscape plots of the Sub-polar Urals. In the following: estimates of productivity are presented in the most simple form - summarized relative numbers (specimens / 100 trap- 
days) of the same five most abundant species that were used (Table 4). We consider such an estimate quite adequate for comparison. As the data show, the highest rodent numbers are registered on the western foothill plot. This confirms that habitats of this plot have more favorable conditions for rodent communities and greater ecological capacity resulting in greater polydominance of fauna. Rodent numbers are 3 times lower in western mountainous part than in the previous case. In our opinion this indicates that biotopes of this plot have a lower capacity, which results into less equitability of rodent species. In the eastern mountainous part rodent numbers are 1,5 times lower than in the western foothills. We regard this to be a result of the lower resources of the western foothill floodplain which are hardly more abundant than on the western mountainous plot. Rodent communities can maintain a higher level of productivity, due to habitat diversity by animals' redistribution to different habitats with environmental changes in different years. Rodent communities of the eastem foothill plain are the least productive among all areas of the Sub-polar Urals which are consistent with the small number of species contained and their high monodominance in this area. This is determined by the relative poverty and homogeneity of habitats. It should be noted that when discussing rodent communities productivity determination using the ecological capacity of habitats, we refer to the whole complex of conditions and resources, and by no means identifying any of them as most important. Besides, though rodent communities productivity is determined by ecological capacity of their habitats, it is far beneath what is potentially possible as rodents use only a small part of the resources that determine the habitats capacity. That is why wide fluctuation in rodent population numbers do not result in any catastrophic disturbances of their habitats.

Such relationship between rodents communities productivity and their habitats capacity is important in the historical formation of communities. We note that rodent communities in the mountainous part are lower with an eastward monotonous succession of changes. These have been already noted in other parameters of compared faunas from different landscape plots of the Sub-polar Urals. We suppose that the character of rodent fauna of mountainous part of the eastern slope show that zoogeographic border between faunas of taiga zone of the Western Siberia and the European North passes precisely trough this area. Its position is determined by both modern landscape and ecological conditions and history of recent fauna formation.

Therefore the situation in the mountainous part of the eastern slope should be considered in greater detail. Two landscape zones are clearly distinguished there: the highest central part of the range with pronounced subzone of cold deserts and the middle mountain, where only mountain 
tundras represent the goltsy belt although significant valleys are been eroded by rivers originating in the main watershed. Is this connected with the differences in rodent populations in the given zones? Rodents species lists for central part of the range and middle mountain are presented below:

Central part of the range
1. Northern red-backed vole
2. Grey large-footed red-backed vole
3. Common red-backed vole
4. Middendorf's vole
5. Short-tailed field vole
6. Northern birch mouse
7. Collared lemming
8. European water vole

Middle mountains

1. Northern red-backed vole

2. Grey large-footed red-backed vole

3. Common red-backed vole

4. Short-tailed field vole

5. Root vole

6. Wood lemring

As these lists show, differences between rodent communities composition of the two compared landscape localities have considerable level of significance $\left(I_{0}=0,58\right)$. Root vole and wood lemming are absent in the central part; Middendorf's vole, northern birch mouse, collared lemming, and European water vole are absent in the middle mountain. However the fauna's similarity determined by species lists is most probably underestimated.

Comparing these two lists the following should be kept in mind:

1) Middendorf's vole is found in the foothill plain and absent in the listings of the middle mountain

2) The European water vole is recorded in the central part of the range and is common on the foothill plains so like the previous species, it is most probably present in middle mountains although as rare as in the central part of the range

3) wood lemming is only rarely captured throughout the whole range and accordingly could remain hidden in some areas, for example in the central part. When the above data are considered, the differences between the species lists for the middle mountain and the central part of the range will have substantially less effect $(=0,82)$. But still this index is less than index of similarity between mountain faunas of the eastern and western slopes (Table 5). Its true value evidently lies somewhere between these limits and suggests why these differences are significant. Thus, on the eastern slope, faunas differ significantly not only between mountains and adjacent plain but also between different mountain landscape zones.

Rodent distribution pattern in the altitudinal belts of the Sub-polar Utals has some distinctive features. Relevant data are presented in Tables 6-7. 
RODENT COMMUNITIES IN THE SUB-POLAR URAL MOUNTAINS

Table 6. Relative numbers (specimen/100 trap-days) and rodents species ratio in the different altitudinal belts of the central part of the range in the Sub-polar Urals.

\begin{tabular}{|c|c|c|c|c|c|c|}
\hline \multirow[b]{2}{*}{ Species } & \multicolumn{2}{|c|}{ Goltsy belt* } & \multicolumn{2}{|c|}{ Subgoltsy bejt ${ }^{* *}$} & \multicolumn{2}{|c|}{ Mountain laiga belt } \\
\hline & 1 & 2 & $1^{\circ}$ & 2 & 1 & 2 \\
\hline Northern red-backed vole & 1.0 & 0.23 & 1.9 & 0.19 & 4.1 & 0.61 \\
\hline Grey large-footed red-backed vole & 2.6 & 0.59 & 3.5 & 0.35 & 0 & 0 \\
\hline Common red-backed vole & 0.1 & 0.02 & 2.9 & 0.29 & 1.5 & 0.22 \\
\hline Middendorf's vole & 0.7 & 0.16 & 0 & 0 & 0 & 0 \\
\hline Short-tailed field vole & + & -.. & 1.2 & 0.12 & 1.0 & 0.15 \\
\hline Root vole & 0 & 0 & 0 & 0 & 0 & 0 \\
\hline Wood lemming & 0 & 0 & 0 & 0 & 0 & 0 \\
\hline Collared lemming & + & - & 0 & 0 & 0 & 0 \\
\hline Northem birch mouse & + & - & 0.4 & 0.04 & 0.1 & 0.01 \\
\hline Total numbers & 4.4 & 1.00 & 9.9 & 0.99 & 6.7 & 0.99 \\
\hline Total number of species & 7 & 5 & 4 & & & \\
\hline $\mathrm{H}^{\prime}$ & & & & & & \\
\hline $\mathrm{U}$ & & & & & & \\
\hline
\end{tabular}

Notes for tables 6-7: 1, relative numbers; 2, species share; (+), species registered outside count lines.

* altitudinal analog of alpine belt; ** altitudinal analog of subalpine belt.

Table 7. Relative numbers (specimen/100 trap-days) and rodents species ratio in the different altitudinal belts of middle mountain on Sub-polar Urals.

\begin{tabular}{|c|c|c|c|c|c|c|}
\hline \multirow[b]{2}{*}{ Species } & \multicolumn{2}{|c|}{ Goltsy belt* } & \multicolumn{2}{|c|}{ Subgoltsy belt* } & \multicolumn{2}{|c|}{ Mountain taijga belt } \\
\hline & 1 & 2 & 1 & 2 & 1 & 2 \\
\hline Northern red-backed vole & 1.0 & 0.15 & 6.5 & 0.71 & 6.2 & 0.58 \\
\hline Grey large-footed red-backed vole & 5.5 & 0.85 & 2.2 & 0.24 & 1.4 & 0.13 \\
\hline Common red-backed vole & 0 & 0 & 0 & 0 & 2.8 & 0.26 \\
\hline Middendorf's vole & 0 & 0 & 0 & 0 & 0 & 0 \\
\hline Short-tailed field vole & 0 & 0 & 0.4 & 0.04 & 0.1 & 0.01 \\
\hline Root vole & 0 & 0 & 0 & 0 & 0.2 & 0.02 \\
\hline Wood lemming & 0 & 0 & 0 & 0 & + & - \\
\hline Collared lemming & 0 & 0 & 0 & 0 & 0 & 0 \\
\hline Northern birch mouse & 0 & 0 & 0 & 0 & 0 & 0 \\
\hline Total numbers & 6.5 & 1.00 & 9.1 & 0.99 & 10.7 & 1.00 \\
\hline Total number of species & \multicolumn{2}{|c|}{2} & \multicolumn{2}{|c|}{3} & \multicolumn{2}{|c|}{6} \\
\hline $\mathrm{H}^{\prime}$ & \multicolumn{2}{|c|}{0.430} & \multicolumn{2}{|c|}{0.714} & \multicolumn{2}{|c|}{1.056} \\
\hline $\mathbf{U}$ & \multicolumn{2}{|c|}{0.245} & \multicolumn{2}{|c|}{0.231} & \multicolumn{2}{|c|}{$0.22 \%$} \\
\hline
\end{tabular}

As data of the Tables show, 9 small terrestrial rodent species recorded in the mountainous part of the Sub-polar Urals. 2 typical zonal tundra species Middendorf's vole and collared lemming - add to those registered in the North Urals. Both occurred only in the goltsy belt. Wood lemming and root vole were not found in the upper belts. The other species extend into the high mountain. Grey large-footed red-backed vole dominates in goltsy belt and central part of the range as distinct from the North Urals where northern red- 
backed vole is a dominant species. Short-tailed field vole and northern birch mouse display pronounced preference of subgoltsy belt.

Considerable differences in rodent assemblages structure with changes in altitude belts exist between central part of the range and middle mountain in the Sub-polar Urals. Changes of number of species in goltsy, subgoltsy and mountain taiga belts are opposite in these two landscape areas: in the first case it decreases from the top down, and in the second instance it increases.

The greatest species number recorded for the goltzy belt of the central part of the range in our opinion can be explained by the greater degree of interconnection of similar habitats in this part of the mountain system. This allows rodent populations interchange between different plots along the range in comparison with more isolated from each other lateral ranges. Rodent total relative numbers also varies between these two plots of the eastern slope. It increases successively from the top down in middle mountain whereas in watershed area the greatest numbers registered in subgoltsy belt and the least in the goltsy (like in the North Urals). Shannon-Weaver diversity index changes in a similar manner in these landscape areas: in the central part it has maximum value in subgoltsy belt but minimum in mountain taiga; in middle mountain this parameter increases from the top down like the previous one. Inequitability index changes in both cases and in opposite directions. Thus, most abundant, diverse and polydominant communities are concentrated in subgoltsy belt in the central part of the range and in mountain taiga in middle mountain. Individual species are also differently distributed over altitudinal belts in these two areas. Northern red-backed vole has already been discussed above. Grey large-footed red-backed vole is most abundant in subgoltsy belt and not recorded at all in mountain taiga of the central part. In middle mountain it has maximum abundance in goltsy belt and minimum in the mountain taiga. Its share in assemblages here changes accordingly. Common red-backed vole is also most abundant in the subgoltsy belt of the watershed part, where it exceeds in abundance even that of the northern redbacked vole which dominates throughout the area. In the goltsy belt this species is less abundant. In the second considered area the common redbacked vole was recorded only in the mountain taiga belt.

We suppose that the greater degree of participation of common redbacked vole in rodent communities of the central part of mountain range is a result of invasion of this species to the Sub-polar Urals. This occurred precisely through the watershed ranges during its northward expansion and later by invading middle mountains by descending from the first area to the second. Absence of the northern birch mouse in middle mountains and root vole and wood lemming in the central area has been discussed previously. In our opinion described differences in rodent population structure between dif- 
ferent altitudinal belts of the two landscape sites of mountainous part of the Sub-polar Urals indicate that mechanisms of these animals communities formation differ significantly on watershed and lateral ranges of Urals Mountains.

Acknowledgements. This work was supported by grants from RFBR (N 0104-96403) and Miristry of Education of the Russian Federation (N E02-6.0-174).

\section{References}

ANDREEV, V. L. (1979). Classification system in biogeography and systematics, p. 3-59. Vladivostok. (In Russian).

ARHIPOVA, N. P. \& YASTREBOV, E.V. (1971). How the Urals Mountains were discovered. Perm Publishing House, Perm, 197 pp. (In Russian).

BALAHONOV, V. S. (1981). Small mammals in altitudinal belts of Sub-polar Urals and analogous landscape zones of Nothern Priobye and South Yamal, pp. 3-18. Sverdlovsk. (In Russian).

BARRY, R. T. (1984). Weather and climate in motntains. L.: Hydrometeorological data, 312 pp. (In Russian).

BERDYUGIN, K. I. (1984). Some aspects of red vole ecology in connection with its biotopic distribution within its range. In Morphology and population ecology of manmals. Sverdlovsk, pp. 87-102. (In Russian).

BOLSHAKOV, V. N. \& BERDYUGIN, K. I. (1986). History and current state of faunal research in the Ural mountains. In Small mammals of the Ural mountains. Sverdlovsk, pp. 3-16. (In Russian).

BOLSHAKOV, V. N. \& BERDYUGIN, K. I. (1990). Small mammals in the upper belts of the Ural Mountains. Pirineos, 135: 3-12.

BOYKOV, V. N. (1981). Mammals and birds species composition and distribution in biotops of forest-tundra of low Ob river. Sverdlovsk, Pp. 38-62. (In Russian).

FLEROV, K. K. (1933). Issues on mammals of Polar Urals and Western Siberia. News of AN SSSR, 1933, series 3, div. of math and natural sciences, pp. 445472. (In Russian).

GROMOV, I. M. \& POLYAKOV, I. Y. (1977). Fauna of the USSR. Mammals. Vol. 3, issue 8. Microtinae A. Ed. Nauka. 509 pp. (In Russian).

KEMMERIH, A. O. (1961). Hydrogeography of the North, Sub-polar and Polar Urals. M.: Publishing House of USSR Ac. Sci. 139 pp. (In Russian). 
KUPRIYANOVA, I. F. \& NEDOSEKIN, I. B. (1986). Small mammals number and methods for estimating it in middle taiga of European North of the USSR. Master thesis. Ufa, pp. 327-328. (In Russian).

LIDER, V. A. (1976). Quaternary deposits of Urals. Ed. Nedra, p. 144. (In Russian).

MAKUNINA, A. A. (1976). Urals landscapes. MGU Publishing House. 158 pp. (In Russian).

MARVIN, M. Y. (1957). Muroidaea rodents agricultural pests in Sverdlovskaya oblast. Scientific notes of Urals State University, Issue 15, pp. 3-8. (In Russian).

MAGURRAN, A. E. (1992). Ecological diversity and its meastirement. Ed. Moskow. 182 pp. (initial edition: London, Sydney, 1988).

OCHIAI, A. (1957). Zoogeographical studies on Soleoid fishes found in Japan and in neighbouring regions. Bull. Japan. Sci. Fisheries, 22 (9): 522-525.

PESENKO, U. A. (1982). Principles and methods of quantitative analysis in faunistic research. Ed., Nauka. 287 pp. (In Russian).

POKROVSKAYA, I. V. (1983). Diverse rodents of north taiga light forests of the West Siberia. In Rodents: Abstracts of $6^{\text {th }}$ all-Union conference, pp. 425-427. (In Russian).

RAEVSKIY, V. V. (1982). Vertebrate animals of Northern Trans-Urals. Ed. Nauka. 146 pp. (In Russian).

RAMASANOVA, F. R. (1982). Plants and animals of Sihote-Alinskiy natural reseroe. Ed., Nauka. 304 pp. (In Russian).

RAMASANOVA, F. R. (1984). Small mammals population of Malaya Sosva natural reserve, pp. 24-32. (In Russian).

TOPORKOVA, L. Y. (1957). Rodents of north-eastern areas of Sverdlovskaya oblast. Scientific notes of Urals State University, issue 15: 16-19. (In Russian),

TOPORKOVA, L. Y. (1959). Materials on mammalian fauna of the Sub-Polar Ural. Issues of Urals Division of MOIP, 2: 133-136. (In Russian).

TOPORKOVA, L. Y. (1959). On vertical distribution of small mammals in the Urals. Abstracts of scientific conference of biological department of UrSU, PP. 38. Sverdlovsk. (In Russian).

TUR'EVA, V. V. (1952). Myomorpha rodents of forest part of Komi ASSR. Scientific pupers of Komi branch of USSR Ac. Sci. N 1: 53-63. (In Russian).

TUR'EVA, V. V. (1971). Small mammals fauna of North-East of Komi republic. Abstracts of scientific conference of Institute of Biology: 115-116. Siktivkar. (In Russian).

TUR'EVA, V. V. (1977). A short ecological-geographical issue of animals of the western slope of Sub-Polar Ural, 34: 3-8. (In Russian). 
RODENT COMMUNITIES IN THE SUB-POLAR URAL MOLNTAINS

TUR'EVA, V. V. (1977). Ecological-faunistic review of small mammals of the western slope of Sub-polar Urals. In The world of natural reserves in the western part of Pre-Polar Urals. Siktivkar, 34: 30-43. (In Russian).

TUR'EVA, V. V; NOVOZHILOVA, E. N. \& YUSHKOV, V. F. (1979). Small mammals and their parasites fauna on the western slope of Sub-Polar Urals. In Mammals of Ural mountains. Sverdlovsk: 79-80. (In Russian). 